\title{
Hubungan antara Persepsi Terhadap Iklim Sekolah dengan Penyesuaian Diri pada Siswa SMA Berbasis Ketarunaan
}

\author{
PUSPITA NUR AULIA \& IWAN WAHYU WIDAYAT* \\ Departemen Psikologi Pendidikan dan Perkembangan, Fakultas Psikologi Universitas Airlangga
}

\begin{abstract}
ABSTRAK
Penelitian ini didasari dari fenomena dimana siswa SMA berbasis ketarunaan mengalami kesulitan dalam menyesuaikan diri dengan lingkungan baru, yang mengakibatkan nilai akademis menurun dan munculnya masalah. Penelitian ini bertujuan untuk mengetahui hubungan yang terdapat di antara persepsi terhadap iklim sekolah dengan penyesuaian diri pada siswa SMA berbasis ketarunaan. Penelitian ini adalah penelitian kuantitatif dengan metode pengambilan data berupa survey secara daring. Sampel dari penelitian ini adalah 153 siswa yang bersekolah di SMA berbasis ketarunaan dengan kategori kelas 11 dan 12 yang terdiri dari 74 laki-laki dan 79 perempuan. Alat ukur yang digunakan meliputi Skala Penyesuaian Diri untuk mengukur penyesuaian diri dengan reliabilitas 0,837 dan Learning Environment Inventory mengukur persepsi terhadap iklim sekolah dengan reliabilitas 0,657 . Hasil analisis variabel penelitian menunjukkan nilai signifikansi sebesar 0,274 . Hasil tersebut menunjukkan bahwa terdapat hubungan antara persepsi terhadap iklim sekolah dengan penyesuaian diri pada siswa SMA berbasis ketarunaan.
\end{abstract}

Kata kunci: penyesuaian diri, persepsi terhadap iklim sekolah

\section{ABSTRACT}

This research is based on the phenomenon in which ketarunaan-based high school students have difficulty adjusting to a new environment, which results in decreased academic scores and problems. This study aims to determine the relationship that exists between perceptions of school climate and personal adjustment in high school students. The sample of this study was 153 students who attended ketarunaan-based high school with the category 11 and 12 grade consisting of 74 boys and 79 girls. Measuring instruments used include the Personal Adjustment Scale to measure adjustment with a reliability of 0.837 and the Learning Environment Inventory to measure perceptions of school climate with a reliability of 0.657 . The results of the analysis of the research variables showed a significance value of 0.274 . These results indicate that there is a relationship between perceptions of school climate and personal adjustment in high school students.

\section{Keywords: perception of school climate, personal adjustment}

Buletin Penelitian Psikologi dan Kesehatan Mental (BRPKM), 2021, Vol. 1(1), 425-434

*Alamat korespondensi: Fakultas Psikologi Universitas Airlangga, Kampus B Universitas Airlangga Jalan

Airlangga 4-6 Surabaya 60286.Surel: iwan.widayat@psikologi.unair.ac.id Naskah ini merupakan naskah dengan akses terbuka dibawah ketentuan the Creative Common Attribution License (CC-BY-4.0) (http://creativecommons.org/licenses/by/4.0), sehingga penggunaan, distribusi, reproduksi dalam media apapun atas artikel ini tidak dibatasi, selama sumber aslinya disitir dengan baik. 


\section{P E N D A H U L U A N}

Sekolah berasrama adalah sekolah dimana sebagian besar atau seluruh siswa bermukim disekolah selama menimba ilmu di sekolah yang dituju (Kementerian Pendidikan dan Kebudayaan, 2018). Dalam penyelenggaran pendidikan dengan model asrama dibutuhkan pengelolaan yang berbeda dengan pengelolaan di sekolah regular. Hal tersebut disebabkan karena proses pembelajaran berlangsung dalam segala aktivitas siswa selama berada di sekolah. (Kementerian Pendidikan dan Kebudayaan, 2018). Sekolah ketarunaan merupakan sekolah yang menggunakan pola pendidikan ala militer dalam kurikulum khususnya (Kementerian Pendidikan dan Kebudayaan, 2018). Kegiatan keseharian dilakukan di sekolah berbasis ketarunaan berlandaskan kedisplinan tinggi secara teratur dan terstruktur sepanjang hari. Dalam jenis sekolah seperti ini kehadiran peserta didik di sekolah adalah mutlak, maka pola yang diterapkan adalah sekolah asrama penuh (Kementerian Pendidikan dan Kebudayaan, 2018).

Di Indonesia, penerapan sistem pendidikan ketarunaan pada SMA sudah tidak asing. Menteri Pertahanan dan Keamanan, Jenderal LB Moerdani memiliki visi untuk membangun sekolah yang mendidik individu terbaik dari seluruh Indonesia dan menghasilkan lulusan yang dapat melanjutkan cita-cita para proklamator (Nusantara, 2009). Visi ini kemudian diteruskan dengan perjanjian kerja sama antara TNI dan Taman siswa, yang merupakan organisasi kependidikan pertama di Indonesia. Dari perjanjian ini, hadirlah Lembaga Perguruan Taman Taruna Nusantara (LPTTN) yang kemudian mendidirkan SMA Taruna Nusantara di Magelang. Pendirian SMA ini kemudian memprakarsai model Pendidikan SMA dengan sistem ketarunaan (Nusantara, 2009). Setelah pendirian SMA Taruna Nusantara, pendidikan ketarunaan mulai sering ditemui di Indonesia. Seperti SMA Negeri 1 Matauli di Sumatera Utara, SMA Taruna Bumi Khatulistiwa di Kalimantan Barat, SMA Terpadu Krida Nusantara.

Jenis sekolah ini, belum banyak diteliti pada bidang psikologi. Peneliti semakin tertarik untuk meneliti hal-hal yang bisa terjadi dari perpindahan siswa berlatar Sekolah Menengah Pertama (SMP) regular ke Sekolah Menengah Atas (SMA) dengan sistem ketarunaan. Namun, transisi siswa dari sekolah lanjutan pertama ke sekolah lanjutan atas jarang dibahas secara khusus oleh para ahli. Awal dari pergerakan ilmu psikologi pendidikan adalah untuk membantu siswa agar dapat sukses dalam melakukan transisi ke Sekolah Menengah Atas (Mizelle \& Irvin, 2000). Meskipun demikian, transisi tersebut belum banyak diteliti, khususnya transisi pada siswa SMP regular yang melanjutkan pendidikannya ke SMA berasrama ketarunaan.

Proses transisi sekolah ini kemudian sangat penting karena banyak dari siswa yang mengalami kesulitan dalam bertransisi ke SMA. Banyak dari siswa yang mengalami drop out, seringkali sesaat setelah siswa memasuki sekolah, atau siswa tidak dapat mengejar pelajaran di kelas dan tidak dapat lulus dengan nilai yang selama ini diperoleh. Transisi siswa yang memasuki sekolah berasrama penting untuk diteliti karena SMA berasrama memiliki tuntutan yang lebih tinggi jika dibanding dengan SMA non-asrama. Transisi siswa ke sekolah asrama mengarahkan siswa pada perubahan lingkungan serta tuntutan yang baru. Ketika siswa memasuki sekolah yang baru, siswa mengalami perubahan mulai dari lingkungan sekolah dan tempat tinggal yang baru, pengajar serta teman-teman yang baru, jadwal kegiatan yang ketat, peraturan dan dinamika kehidupan asrama, serta perubahan-perubahan lain sebagai akibat jauh dari orang tua (Stewart, 2014).

Menurut penelitian yang dilakukan oleh Purwaningsih (2013) siswa yang hidup di sekolah berasrama menunjukkan masalah-masalah terkait penyesuaian diri. Masalah tersebut seperti tidak terbiasa dengan kehidupan asrama yang mengatur berbagai aspek perilaku serta ritme kegiatan dalam seharihari yang cukup padat. Menurut Hadwen (1968) kesulitan dalam menyesuaikan diri dapat membuat

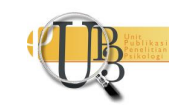


peserta didik merasa tertekan, mengalami stress, prestasi belajar menurun, melanggar peratuan sekolah dan berbuat onar. Penelitian yang dilakukan oleh Rahmayanti \& Lubis (2013) menyatakan sebagian siswa tahun pertama juga mengalami masalah penyesuaian diri, hal ini ditunjukkan dengan kurangnya tanggung jawab dalam mematuhi peraturan sekolah yang menjadi tuntutan seorang siswa.

Penyesuaian diri merupakan salah satu persyaratan penting bagi terciptanya kesehatan mental remaja. Penyesuaian diri merupakan suatu proses dimana individu berusaha keras untuk mengatasi atau menguasai kebutuhan dalam diri, ketegangan, frustasi, dan konflik, tujuannya untuk mendapatkan keharmonisan dan keselarasan antara tuntutan lingkungan dimana dia tinggal dengan tuntutan didalam dirinya (Schneiders, 1964). Penyesuaian diri terhadap tuntutan dan perubahan tersebut diperlukan remaja sebagai mekanisme yang efektif untuk mengatasi stress dan dan menganulir terjadinya krisis psikologis pada remaja (Isakson \& Jarvis, 1999)

Keberhasilan penyesuaian diri siswa pada tahun pertama menentukan kemampuan siswa dalam menyesuaikan diri di tahun-tahun setelahnya. Banyak siswa yang menderita dan tidak mampu mencapai kebahagiaan didalam hidupnya karena ketidakmampuannya dalam menyesuaikan diri dengan baik di sekolah maupun di masyarakat (Jia et al., 2009). Peneliti mencantumkan penelitianpenelitian sebelumnya dengan berbagai tipe sekolah berasrama, namun peneliti belum menemukan data secara empirik bagaimana gambaran penyesuaian diri, baik dampak maupun faktor yang mempengaruhi pada siswa SMA berbasis ketarunaan.

Peneliti kemudian melakukan preliminary study terkait masalah-masalah yang dihadapi oleh peserta didik pada SMA berbasis ketarunaan. Peneliti menyebarkan angket secara daring untuk diisi oleh siswa SMA berbasis ketarunaan. Dari 80 responden, hanya 3 responden yang mengaku tidak mengalami kesulitan saat menyesuaikan diri, sedangkan 77 responden yang mengisi mengaku mengalami kesulitan dalam menyesuaikan diri di lingkungan sekolah yang baru. Mayoritas responden sebanyak $21(27,3 \%)$ merasa kesulitan dalam mengikuti kegiatan sekolah yang padat, diikuti dengan 19 (24,6\%) responden yang mengalami homesick. Mayoritas responden sebanyak 24 (31,1\%) merasa kesulitan dalam mengikuti kegiatan belajar mengajar, diikuti dengan 18 (22,0\%) responden yang mengalami kesulitan dalam mengendalikan emosi. Penurunan nilai mata pelajaran juga mendapatkan respondennya sebanyak $16(20,7 \%)$.

Salah satu dari lima faktor yang mempengaruhi penyesuaian diri adalah kondisi lingkungan (Schneiders, 1964). Kondisi lingkungan seperti rumah, keluarga serta sekolah memberikan pengaruh pada penyesuaian individu. Suasana lingkungan sekolah tempat peserta didik dapat mempengaruhi penyesuaian diri peserta didik hal ini berdampak pada bagaimana individu tersebut melakukan penyesuaian diri dalam lingkungan yang lebih besar (Schneiders, 1964). Lingkungan sekolah telah diakui secara universal sebagai media yang kuat untuk mempengaruhi kehidupan intelektual, sosial dan moral pada siswa (Behaghel et al., 2017).

Lingkungan sekolah tidak hanya mengacu pada keadaan lingkungan secara fisik tapi kualitas dan karakter dari lingkungan sosial sekolah yang merupakan kumpulan dari terbentuknya norma, nilai, peran dan struktur dari sebuah sekolah (Gage et al., 2016) sehingga dalam beberapa penelitian lingkungan sekolah sering disebut sebagai iklim sekolah (Hong et al., 2018). Iklim sekolah yang baik juga harus dipersepsikan dengan baik oleh peserta didik. Persepsi peserta didik terhadap iklim sekolah bersifat subyektif, sehingga penilaian peserta didik terhadap norma dan kondisi sekolahnya dapat berbeda dengan keadaan yang sebenarnya (Maxwell et al., 2017). Iklim sekolah positif ternyata dapat dipersepsikan oleh peserta didik secara negatif. Perbedaan ini kemudian mempengaruhi tingkah laku serta perasaan peserta didik di sekolah (Jia et al., 2009). 
Persepsi siswa terhadap iklim sekolah mungkin berkontribusi dalam proses individu untuk memiliki hubungan pertemanan yang positif, memiliki gambaran diri yang positif dan dapat mengatasi masalah transisi yang dihadapi (Roeser et al., 2000). Penelitian sebelumnya yang dilakukan oleh Kuperminc (2001) menjelaskan bahwa persepsi yang baik pada iklim sekolah dapat berkontribusi sebagai faktor pelindung untuk mengatasi efek dari kecenderungan individu ketika mengalami masalah dalam penyesuaian diri.

Penelitian ini hadir untuk meneliti dan mengetahui apakah terdapat hubungan antara persepsi terhadap iklim sekolah dengan penyesuaian diri pada siswa SMA berbasis ketarunaan. Seperti bagaimana hubungan kedua variabel tersebut, Serta menggambarkan hubungan yang ada diantara kedua variabel tersebut.

\section{E T O D E}

Pendekatan yang digunakan pada penelitian ini adalah pendekatan kuantitatif-eksplanatoris. Penelitian ini menggunakan teknik random sampling. Pengambilan data pada penelitian ini dilakukan dengan teknik survey dengan menggunakan kuesioner. Pengambilan data dilakukan secara daring. Pengambilan data dilakukan selama kurang lebih 15 hari. Penelitian ini melibatkan siswa SMA berbasis ketarunaan.

Variabel independen dalam penelitian ini adalah penyesuaian diri. Skala variabel penyesuaian diri pada penelitian ini disusun oleh Lutfi Irwansyah (2017) berdasarkan teori penyesuaian diri yang dikemukakan oleh Schneiders (Schneiders, 1964). Reliabilitas skala penyesuaian diri setelah uji terpakai adalah 0,837 . Model skala yang digunakan dalam skala penyesuaian diri di sekolah adalah skala Likert (Summated-Rating Scale). Pernyataan-pernyataan tersebut memiliki 4 (empat) alternatif jawaban, kelima alternatif jawaban tersebut adalah Sangat Setuju (SS), Setuju (S), Tidak Setuju (TS), dan Sangat Tidak Setuju (STS).

Variabel dependen dalam penelitian ini adalah persepsi terhadap iklim sekolah. Pengumpulan data variabel persepsi terhadap iklim sekolah pada penelitian ini menggukan skala Learning Environment Inventory (LEI) yang disusun oleh Frasher (1989). Berdasarkan teori persepsi terhadap iklim sekolah yang dikemukakan oleh Frasher (1989). Skala ini terdiri dari lima aspek yaitu: cohesiveness, friction, satisfaction in the classroom, competitiveness, difficulty. Reliabilitas skala LEI setelah dilakukan pengambilan data adalah sebesar 0,657.

Uji validitas dari alat ukur yang digunakan oleh peneliti dibantu oleh Dosen Fakultas Psikologi Universitas Airlangga yang berperan dalam memberi professional judgement. Hal ini memiliki tujuan agar skala yang diadaptasi telah sesuai atau memiliki makna yang tidak berbeda jauh dengan skala aslinya, sehingga hasil dari penelitian yang dilaksanakan tidak jauh dari skala yang diadaptasi.

Analisis data pada penelitian ini dilakukan dengan menggunakan teknik Spearman Rho dengan bantuan IBM Statistic SPSS 23 for Windows. Penggunaan teknik Spearman Rho dikarenakan data penyesuaian diri dengan persepsi terhadap iklim sekolah memiliki distribusi data tidak normal namun memiliki hubungan yang linear. 


\section{HAS IL P E N ELIT IAN}

Pengambilan data dalam penelitian ini dilakukan secara online. Pengambilan data dilakukan selama kurang lebih 15 hari, sejak tanggal 19 November 2020 hingga 21 November 2020. Pengambilan data secara online dilakukan peneliti dengan menyalin butir-butir aitem pada media google form. Penelitian ini dilakukan pada siswa yang bersekolah pada SMA berbasis ketarunaan. Total kuesioner yang terisi adalah sebesar 153 partisipan. Berdasarkan kuesioner yang diterima dapat diketahui bahwa karakteristik partisipan penelitian ini berdasarkan jenis kelaminnya secara total partisipan yang berpartisipasi terdiri dari 153 partisipan, 153 partisipan dibagi menjadi $74(48,4 \%)$ laki-laki dan 79 (51,6\%) perempuan. Berdasarkan kelasnya responden dibagi menjadi kelas 11 sebanyak 70 responden $(45,8 \%)$ dan kelas 12 sebanyak 83 responden $(54,2 \%)$.

\section{Analisis Deskriptif}

Hasil analisis statistik pada 153 partisipan menunjukkan nilai variabel persepsi terhadap iklim sekolah dan penyesuaian diri. Adapun nilai rata-rata dari variabel persepsi terhadap iklim sekolah 109,8 dan nilai standar deviasinya berada di 7,726. Variabel persepsi terhadap iklim sekolah memiliki nimai minimum 90 dan nilai maksimal 136.

Nilai skewness pada variabel persepsi terhadap iklim sekolah 0,606 dan nilai kurtosis yang yang didaparkan adalah 0,682. Kemudian untuk variabel penyesuaian diri didapatkan nilai rata-rata 111,9 dan nilai standar deviasi sebesar 8,963. Variabel penyesuaian diri memiliki nilai maksimal 131 dan nilai minimum 80. Lalu untuk nilai skewness yang didapatkan pada variabel penyesuaian diri adalah -0,674 dan nilai kurtosis yang didapatkan sebesar 1,321.

Skewness adalah suatu nilai yang menunjukkan tentang kesimetrisan distribusi data. Nilai pada skewness ini dapat pula digunakan untuk melihat apakah sebuah data penelitian itu dapat dikatakan normal atau tidak. Data dianggap normal jika mengalami penyimpangan positif yaitu apabila memiliki tanda positif dan ketika skor berkerumunan ke kiri di nilai rendah. Selain itu, data dikatakan normal bila mengalami penyimpangan negative, yaitu ketika memiliki tanda negative (-) dan skor mengelompok pada sisi kanan grafik (Pallant, 2005).

Selanjutnya, kurtosis adalah nilai yang digunakan untuk melihat distribusi data, apakah data lebih memuncak atau mendatar. Kurtosis yang bernilai positif menunjukkan bentuk yang relatif runcing dan distribusi data yang mengumpul di tengah, sementara kurtosis yang bernilai negatif menunjukkan bentuk yang relatif datar serta distribusi data yang menyebar (Pallant, 2005).

\section{Uji Asumsi}

Setelah melakukan analisis deskriptif, penulis melakukan uji asumsi yaitu dengan melakukan uji normalitas dan uji linearitas. Hasil menunjukkan nilai hasil uji normalitas dari variabel persepsi terhadap iklim sekolah dan penyesuaian diri melalui uji Kolmogorov-smirnov. Berdasarkan tabel tersebut, dapat diketahui bahwa nilai signifikansi pada variabel persepsi terhadap iklim sekolah sebesar 0,000 dan penyesuaian diri sebesar 0,028, maka dapat disimpulkan bahwa data yang didapat dalam penelitian ini memiliki persebaran data yang tidak normal. Skor signifikansi pada kedua variabel menunjukkan angka di bawah 0,05, artinya data pada kedua variabel tersebut berdistribusi tidak normal. Berdasarkan hasil di atas, maka dapat disimpulkan bahwa data yang didapat dalam penelitian ini memiliki persebaran data yang tidak normal.

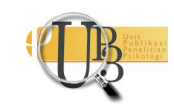


Data yang dikatakan linear adalah data yang memiliki nilai signifikansi dalam tabel anova pada baris linearity menunjukkan angka dibawah 0,05. Berdasarkan tabel di atas, dapat dilihat bahwa nilai signifikansi pada kolom linearity menunjukkan angka 0,000. Hal ini menunjukkan bahwa antara variabel independen dan variabel dependen dalam penelitian ini memiliki hubungan yang linear dikarenakan nilai signifikansi linearitas berada di bawah 0,05.

\section{Uji Korelasi}

Berdasarkan hasil dari uji ormalitas dan uji linearitas yang telah dilakukan sebelumnya, dapat diketahui bahwa data pada penelitian ini berdistribusi tidak normal tetapi memiliki hubungan yang linear. Oleh karena itu data bersifat non-parametrik dan akan menggunakan uji korelasi dengan menggunakan teknik Spearman's rho. Dari pengolahan data yang telah dilakukan didapatkan bahwa variabel persepsi terhadap iklim sekolah dan variabel penyesuaian diri memiliki nilai signifikansi sebesar 0.001 yang artinya terdapat hubungan antar variabel. Selain itu, koefisien korelasi pada kedua variabel tersebut adalah sebesar 0.274 sehingga bisa diartikan sebagai hubungan yang kecil. Arah hubungan dari kedua variabel ini adalah positif yang berarti semakin tinggi persepsi terhadap iklim sekolah yang dimiliki individu, maka semakin tinggi pula penyesuaian diri yang dimiliki individu.

\section{I S K U S I}

Penelitian ini bertujuan untuk mengetahui apakah terdapat hubungan antara persepsi terhadap iklim sekolah dengan penyesuaian diri pada siswa SMA berbasis ketarunaan. Berdasarkan hasil analisis yang telah dilakukan, diketahui bahwa pengujian data pada penelitian ini telah memenuhi syarat uji asumsi normalitas dan linearitas. Hasil uji asumsi normalitas, penelitian ini menunjukkan bahwa distribusi data bersifat tidak normal karena nilai signifikansi pada kedua variabel berada dibawah 0,05. Pada hasil uji linearitas menunjukkan nilai signifikansi 0,000 yang berarti linear Artinya, variabel persepsi terhadap iklim sekolah dan penyesuian diri bersifat linier atau membentuk garis lurus.

Setelah diuji korelasinya dengan menggunakan Spearman's Rho dapat diketahui bahwa hasil analisis mendapatkan niai koefisien sebesar 0,247 yang berarti terdapat hubungan positif antara persepsi terhadap iklim sekolah dengan penyesuaian diri pada siswa SMA berbasis ketarunaan. Hubungan positif tersebut memiliki arti semakin tinggi tingkat persepsi terhadap iklim sekolah pada individu, maka semakin tinggi juga tingkat penyesuaian diri pada individu tersebut. Begitu pula sebaliknya, jika semakin rendah tingkat persepsi terhadap iklim sekolah pada individu, maka semakin rendah pula tingkat penyesuaian diri pada individu.

Bukti adanya hubungan antara kedua variabel yakni persepsi terhadap iklim sekolah dan penyesuaian diri dapat dilihat berdasarkan nilai signifikasnsi yang didapatkan. Dalam penelitian ini telah didapatkan nilai signifikansi sebesar 0,001. Dapat diketahui bahwa nilai signifikansi tersebut lebih kecil dari 0.005 yang artinya hipotesis alternatif (Ha) diterima dan hipotesis nol (Ho) ditolak. Kemudian nilai korelasi pada penelitian ini cenderung rendah, sehingga bisa jadi tingkat persepsi terhadap iklim sekolah tinggi maka belum tentu tingkat penyesuaian diri pada individu tinggi. Nilai rendah pada penelitian ini mungkin saja disebabkan oleh partisipan yang dipilih oleh peneliti memiliki perbedaan karakteristik dari partisipan-partisipan dipenelitian sebelumnya. Partisipan pada penelitian sebelumnya cenderung lebih ke siswa SMP reguler (Mahmudi \& Suroso, 2014) dan 
siswa SMA reguler (Frey et al., 2009)sedangkan pada penelitian ini partisipan yang dipilih adalah siswa SMA berbasis ketarunaan.

Ada banyak faktor mengapa kemudian persepsi terhadap iklim sekolah dengan penyesuaian diri mendapatkan hubungan yang lemah. Seperti penjelasan teori dari beberapa ahli mengatakan penyesuaian diri bersifat relatif, hal tersebut dikarenakan kemampuan setiap individu berbeda dalam mengubah atau memenuhi tuntuntan yang ada pada dirinya (Kuperminc et al., 1997). Kemampuan ini dapat berbeda-beda pada masing-masing individu sesuai dengan kepribadian dan tahap perkembangannya. Kemudian kualitas penyesuaian diri yang dapat berubah-ubah sesuai dengan situasi lingkungan dan kebudayaan tempat penyesuaian diri dilakukan. Menurut penelitian yang dilakukan Husain (2008)karena adanya perbedaan dari masing-masing individu, setiap individu memiliki saat-saat baik dan buruk dalam melakukan penyesuaian diri yang baik karena terkadang individu mengalami situasi yang tidak dapat dihadapi atau diselesaikan.

Hasil penelitian ini kemudian sejalan dengan penelitian yang dilakukan oleh Suprapto (2020)yang juga membahas mengenai persepsi terhadap iklim sekolah dan penyesuaian diri dengan konteks yang mirip, yaitu pada siswa SMA Yogyakarta. Hasil penelitian ini didapatkan dari 52 partisipan dengan teknik analisis korelasi pearson's product moment. Didapatkan skor koefisien korelasi yang tergolong tinggi, yaitu 0,723. Sehingga hipotesis alternatif pada penelitian ini diterima.Skor Koefisien korelasi tersebut bersifat positif dan berada pada kategori kuat. Dimana semakin tinggi persepsi terhadap iklim sekolah siswa maka semakin baik mekanisme penyesuaian diri yang dimiliki siswa. Hasil penelitian ini juga sejalan dengan penelitian yang dilakukan oleh Loukas \& Murphy (2004) yang meneliti persepsi terhadap iklim sekolah dan penyesuaian diri. Hasil penelitian tersebut menunjukkan bahwa terdapat hubungan antara persepsi terhadap iklim sekolah dengan penyesuaian diri. Dimana persepsi terhadap iklim sekolah menjadi salah satu faktor protektif bagi siswa ketika melakukan proses penyesuaian diri dengan lingkungan sekolah baru.

Berdasarkan uraian yang telah dijelaskan oleh peneliti diatas, dapat disimpulkan bahwa hasil penelitian ini mampu menjawab rumusan masalah yang ada di dalam penelitian, yaitu terdapat hubungan yang positif antara persepsi terhadap iklim sekolah dengan penyesuaian diri pada siswa SMA berbasis ketarunaan.. Hal tersebut berarti semakin tinggi tingkat persepsi terhadap iklim sekolah pada siswa SMA berbasis ketarunaan, maka semakin tinggi pula tingkat penyesuaian diri yang dimiliki oleh siswa. Hasil penelitian ini diharapkan dapat menjadi pengetahuan baru terutama bagi siswa SMA berbasis ketarunaan.

\section{S I M P U L A N}

Penelitian ini memiliki kesimpulan bahwa terdapat korelasi positif antara persepsi terhadap iklim sekolah dengan penyesuaian diri pada siswa SMA berbasis ketarunaan. Berarti semakin tinggi persepsi terhadap iklim sekolah yang dimiliki maka semakin tinggi pula penyesuaian diri yang dimiliki pada siswa SMA berbasis ketarunaan. Begitupula sebaliknya, semakin rendah tingkat persepsi terhadap iklim sekolah yang dimiliki maka semakin rendah pula tingkat penyesuaian diri yang dimiliki pada siswa SMA berbasis ketarunaan.

Peneliti selanjutnya diharapkan untuk menggunakan instrumen penelitian terbaru yang memiliki skor reliabilitas yang tinggi, sehingga dapat menggambarkan keadaan yang sebenarnya. Peneliti bisa melakukan penelitian dengan variabel yang berbeda yang dari penelitian ini karena belum banyak

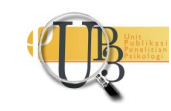


penelitian dengan konteks siswa SMA berbasis ketarunaan. Peneliti selanjutnya diharapkan untuk menggunakan instrumen penelitian terbaru yang memiliki skor reliabilitas yang tinggi, sehingga dapat menggambarkan keadaan yang sebenernya. orang tua diharapkan dpat memberikan pemahaman terkait proses yang terjadi ketika siswa memasuki lingkungan sekolah yang baru.

Pentingnya komunikasi yang baik dengan orang tua dapat memberikan dampak yang baik bagi kelangsungan proses penyesuaian diri siswa SMA berbasis ketarunaan. Pihak orang tua diharapkan dapat memberikan dukungannya dengan selalu memberikan nasihat serta motivasi kepada siswa agar siswa memiliki motivasi untuk menyelesaikan pendidikannya di SMA yang dituju. Pihak orang tua juga diharapkan bisa berkomunikasi dengan institusi sekolah terkait dengan perkembangan siswa di lingkungan sekolah.

\section{U C A P A N T E R I MAKASIH}

Penulis mengucapkan terima kasih kepada pihak-pihak yang telah membantu tercapainya penelitian ini khususnya kepada para pengajar dan segenap sivitas akademik program studi Ilmu Psikologi Fakultas Psikologi Universitas Airlangga, rekan-rekan mahasiswa Psikologi Universitas Airlangga angkatan 2015, seluruh partisipan penelitian, serta pihak-pihak lain yang terkait dalam proses penelitian dan mendukung selama proses pengambilan data.

\section{DEKLARASI POTENSI TERJADINYAKONFLIK KEPENTINGAN}

Puspita Nur Aulia dan Iwan Wahyu Widayat tidak bekerja, menjadi konsultan, memiliki saham, atau menerima dana dari perusahaan atau organisasi mana pun yang akan mengambil untung dari naskah ini, dan telah mengungkapkan bahwa ia tidak memiliki afiliasi selain yang telah disebut di atas.

\section{PUS TAKA ACUAN}

Behaghel, L., Chaisemartin, C. de, \& Gurgand, M. (2017). Ready for boarding? The effects of a boarding school for disadvantaged students. American Economic Journal: Applied Economics, 9(1), 140-164. https://doi.org/10.1257/app.20150090Frey, A., Ruchkin, V., Martin, A., \& Schwab-Stone, M. (2009). Adolescents in transition: School and family characteristics in the development of violent behaviors entering high school. Child Psychiatry and Human Development, 40(1), 1-13. https://doi.org/10.1007/s10578-008-0105-x

Gage, N. A., Larson, A., Sugai, G., \& Chafouleas, S. M. (2016). Student Perceptions of School Climate as Predictors of Office Discipline Referrals. American Educational Research Journal, 53(3), 492-515. https://doi.org/10.3102/0002831216637349

Hadwen, K. M. (1968). Leaving home: Investigating transitioning challenges faced by boarding students and their families Recommended Citation. http://ro.ecu.edu.au/theses/1628

Hong, J. S., Espelage, D. L., \& Lee, J. M. (2018). School Climate and Bullying Prevention Programs. The Wiley Handbook on Violence in Education, 359-374. https://doi.org/10.1002/9781118966709.ch17

Husain, A. A., Kumar, A., \& Husain, A. A. (2008). Academic Stress and Adjustment among High School Students. Journal of the Indian Academy Of, 34(April), 70-73. http://medind.nic.in/jak/t08/s1/jakt08s1p70.pdf

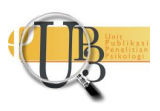


Irwansyah, L. (2017). Efektivitas Backyard Sports Dalam Meningkatkan Penyesuaian Diri dan Menurunkan Stress Santri Baru di Pondok Pesantren. Universitas Airlangga.

Isakson, K., \& Jarvis, P. (1999). The adjustment of adolescents during the transition into high school: A short-term longitudinal study. Journal of Youth and Adolescence, 28(1), 1-26. https://doi.org/10.1023/A:1021616407189

Jia, Y., Way, N., Ling, G., Yoshikawa, H., Chen, X., Hughes, D., Ke, X., \& Lu, Z. (2009). The influence of student perceptions of school climate on socioemotional and academic adjustment: A comparison of chinese and american adolescents. Child Development, 80(5), 1514-1530. https://doi.org/10.1111/j.1467-8624.2009.01348.x

Kementerian Pendidikan dan Kebudayaan. (2018). Pengelolaan Sekolah Berasrama. Jakarta: Pusat Penelitian Kebijakan Pendidikan dan Kebudayaan, Badan Penelitian dan Pengembangan, Kementerian Pendidikan dan Kebudayaan.

Kementerian Pendidikan dan Kebudayaan. (2018). Sekolah Menengah Atas Berasrama. Jakarta: Direktorat Pembinaan SMA.

Kuperminc, G. P., Leadbeater, B. J., \& Blatt, S. J. (2001). School social climate and individual differences in vulnerability to psychopathology among middle school students. Journal of School Psychology, 39(2), 141-159. https://doi.org/10.1016/S0022-4405(01)00059-0

Kuperminc, G. P., Leadbeater, B. J., Emmons, C., \& Blatt, S. J. (1997). Perceived school climate and difficulties in the social adjustment of middle school students. Applied Developmental Science, 1(2), 76-88. https://doi.org/10.1207/s1532480xads0102_2

Loukas, A., \& Robinson, S. (2004). Examining the moderating role of perceived school climate in early adolescent adjustment. Journal of Research on Adolescence, 14(2), 209-233. https://doi.org/10.1111/j.1532-7795.2004.01402004.x

Mahmudi, M. H., \& Suroso, S. (2014). Efikasi Diri, Dukungan Sosial dan Penyesuaian Diri Dalam Belajar. Persona:Jurnal Psikologi Indonesia, 3(02), 183-194. https://doi.org/10.30996/persona.v3i02.382

Maxwell, S., Reynolds, K. J., Lee, E., Subasic, E., \& Bromhead, D. (2017). The impact of school climate and school identification on academic achievement: Multilevel modeling with student and teacher data. Frontiers in Psychology, 8(DEC), 1-21. https://doi.org/10.3389/fpsyg.2017.02069

Mizelle, N. B., \& Irvin, J. L. (2000). Transition from Middle School into High School. Middle School Journal, 31(5), 57-61. https://doi.org/10.1080/00940771.2000.11494654

Nusantara, K. S. (2009). SMA Taruna Nusantara Magelang: Sekolah Terbaik Di Indonesia.

Pallant, J. (2005). SPSS SURVIVAL MANUAL: A step by step guide to data analysis using SPSS for Windows (Version 12).

Purwaningsih, S. (2013). Naskah publikasi hubungan pola asuh demokratis dan kemandirian dengan penyesuaian diri siswa di asrama.

Rahmayanti, T. E., \& Lubis, Z. (2013). Hubungan efikasi diri akademik dan dukungan sosial dengan penyesuaian diri. Analitika: Jurnal Magister Psikologi Uma, 5(2), 43-49. http://ojs.urna.ac.id/index.php.analitika/article/view/784.

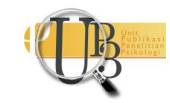


Roeser, R. W., Eccles, J. S., \& Sameroff, A. J. (2000). School as a context of early adolescents' academic and social-emotional development: A summary of research findings. Elementary School Journal, 100(5), 442-471. https://doi.org/10.1086/499650

Schneiders, A. (1964). Personal Adjustment and Mental Health. New York: Holt, Rinehartd and Winston.

Stewart, K. (2014). The Mediating Role of Classroom Social Environment between Teacher Self-Efficacy and Student Adjustment. ProQuest Dissertations and Theses, 153. http://simsrad.net.ocs.mq.edu.au/login?url=https://www.proquest.com/dissertationstheses/mediating-role-classroom-social-environment/docview/1561562197/se2?accountid=12219\%0Ahttps://multisearch.mq.edu.au/openurl/MQ/MQ_SERVICES_PAGE?url_v er=Z39.88-2004\&rf 